\title{
Effect of sowing density and nitrogen top-dress fertilisation on growth and yield of chia (Salvia hispanica L.) in a Mediterranean environment: first results
}

\author{
Rocco Bochicchio, ${ }^{1}$ Roberta Rossi, ${ }^{2}$ Rosanna Labella, ${ }^{1}$ Giovanni Bitella, ${ }^{1}$ Michele Perniola, ${ }^{1}$ \\ Mariana Amato' \\ 'Scuola di Scienze Agrarie, Forestali, Alimentari ed Ambientali, Università della Basilicata, \\ Potenza; ${ }^{2}$ Unità di Ricerca per la Zootecnia Estensiva, Consiglio per la Ricerca \\ in Agricoltura e l'Analisi dell'Economia Agraria, Muro Lucano (PZ), Italy
}

\begin{abstract}
The demand for sources of nutraceuticals has led to the rediscovery and diffusion of traditional crops such as chia (Salvia hispanica L.), whose leaves and fruits are rich in $\Omega 3$ fatty acids and anti-oxidants. Chia originates in Central America but it is rapidly expanding to new areas. A field experiment conducted at Atella in Basilicata (Southern Italy) was set up to test the response of chia to $\mathrm{N}$ top-dress fertilisation $\left(0\right.$ and $\left.20 \mathrm{~kg} \mathrm{ha}^{-1}\right)$ and to sowing density (D1=125, D2=25, D3=8 and $\mathrm{D} 4=4$ plants $\mathrm{m}^{-2}$ ) in a split-plot design with three replications. First results show maximum leaf area index values up to 7.1 and fresh vegetative biomass production at early flowering ranging between 50.87 (D4) and 59.71 (D1) t ha ${ }^{-1}$. Yield increased with plant density: a significantly $(\mathrm{P}<0.01)$ higher production $\left(398 \mathrm{~kg} \mathrm{ha}^{-1}\right)$ was reached in D1. $\mathrm{N}$ top-dressing had a detrimental effect on yield and corresponded to higher lodging and lower maturation percentage of seeds, though
\end{abstract}

Correspondence: Roberta Rossi, Unità di Ricerca per la Zootecnia Estensiva, Consiglio per la Ricerca in Agricoltura e l'Analisi dell'Economia Agraria, via Appia Bella Scalo 85054, Muro Lucano (PZ), Italy.

Tel.: +39.0976.72915.

E-mail: roberta.rossi@entecra.it

Key words: Chia; sowing density; leaf area index; nitrogen; Salvia hispanica; yield.

Acknowledgements: the authors warmly thank Dr. Carmela Bochicchio for her precious help in plant measurement, Azienda Masserie Saraceno for contributing to the experimental setup and management, and Azienda Eurogel di Bagarozza N.\& C. snc for logistics. We sincerely thank Prof. Alessio Pollice for his important advices on the statistical analysis.

Conference presentation: SIA XLIII Congress, Pisa, 2014.

Received for publication: 1 December 2015.

Revision received: 25 June 2015.

Accepted for publication: 25 June 2015.

(C) Copyright R. Bochicchio et al., 2015

Licensee PAGEPress, Italy

Italian Journal of Agronomy 2015; 10:640

doi:10.4081/ija.2015.640

This article is distributed under the terms of the Creative Commons Attribution Noncommercial License (by-nc 3.0) which permits any noncommercial use, distribution, and reproduction in any medium, provided the original author(s) and source are credited. non-significant. Based on our first results it seems worthwhile to continue agronomical trials for chia in herbaceous systems of southern Italy for leaf production based on traditional genotypes, while fruit production might be pursued by adopting high sowing density and the search for longer-day genotypes.

\section{Introduction}

Salvia hispanica L, known as chia, is a multifunctional plant whose food use may be traced back as far as 2500 B.C. Domesticated in Mesoamerica around 2600 B.C. it has been a staple food in Mexico between 1500 and 900 B.C. (Pozo Pozo, 2010). It is an annual herbaceous species belonging to the Labiatae family, and its fruits were one of the four main food source traditionally used in pre-Colombian times. It has recently been re-discovered (Ayerza and Coates, 2009) due to its high content of nutraceuticals and therefore the potential for a functional food and a feed capable of increasing the nutritional value of milk and meat products (Ayerza and Coates, 2006; Peiretti and Meineri, 2008). Fruits (Ayerza and Coates, 2009) and leaves (Peiretti, 2010) are rich in poly-unsaturated fatty acids, anti-oxidants, vitamins, minerals. The oil contained in chia fruits in high percentages $(>30 \%)$ is the richest natural source of $\Omega 3$ fats (Ayerza and Coates, 2002). The market price of the fruits is therefore quite high both for human consumption and for feed.

The plant is a macro-thermal short-day species undergoing a rapid diffusion from the traditional growing areas to new regions of the world (e.g., Australia).

The use of chia for human consumption has recently been approved by the European Parliament and the European Council (European Commission, 2009) but fruit production has never been reported in Europe.

Ayerza and Coates (2009) have studied the crop in different areas in Central America, but research results on agronomic techniques for chia are still few (Bochicchio et al., 2015).

An experiment was set up in Basilicata (Southern Italy) to study the effect of agricultural management on leaf and fruit production of chia. This paper reports the first results of the experiment.

\section{Materials and methods}

Site

The experiment was set up at Masserie Saraceno (Atella - PZ, Southern Italy, Lat. N $40^{\circ} 51^{\prime} 37.59$ ”, Long. E $15^{\circ} 38^{\prime} 49.43$ ”) on a Luvi- 
vertic Phaeozem (Iuss working group, 2006) loam soil with the following characteristics: sand $(50-2000 \mathrm{~mm}) 43.6 \%$, silt $(2-50 \mathrm{~mm}) 34.2 \%$, clay (<2 mm) 22.1\%; pH 6.8; N $1.9 \mathrm{~g} \mathrm{~kg}^{-1}$; phosphates $\left(\mathrm{P}_{2} \mathrm{O}_{5}\right) 50.3 \mathrm{~g} \mathrm{~kg}^{-1}$; potassium oxide $\left(\mathrm{K}_{2} \mathrm{O}\right) 1430 \mathrm{~g} \mathrm{~kg}^{-1}$. The site has an average annual rainfall of $678 \mathrm{~mm}$ concentrated mainly during October-May.

\section{Experimental design}

A chia (Salvia hispanica L.) accession from Peru was sown on 21/06/2013 and grown with non-limiting water supply. The soil was amended with $25 \mathrm{t} \mathrm{ha}^{-1}$ of the solid fraction of biogas digested materials with the following characteristics: dry matter $8.5 \%$; carbon $20.4 \mathrm{~kg}$ $\mathrm{t}^{-1}$; nitrogen (N) $2.8 \mathrm{~kg} \mathrm{t}^{-1}$; ammonium $\left(\mathrm{N}^{-N_{4}}\right) 0.6 \mathrm{~kg} \mathrm{t}^{-1} ; \mathrm{P}_{2} \mathrm{O}_{5} 1.4 \mathrm{~kg}$ $\mathrm{t}^{-1} ; \mathrm{K}_{2} \mathrm{O} 2.5 \mathrm{~kg} \mathrm{t}^{-1}$. Soil tillage consisted of ploughing at $35 \mathrm{~cm}$ and accurate seedbed preparation with chain and rotary harrows given the small seed size (100 seed weight $=1.26 \mathrm{~g}$ ). The crop was hand-weeded.

Top-dress nitrogen fertilisation and sowing density were tested with the following treatments: i) $\mathrm{N}$ top-dress fertilisation applied at 60 days after sowing (DAS) with ammonium nitrate $\left(13.5 \% \mathrm{NH}_{4}{ }^{+}\right.$and $13.5 \%$ $\mathrm{NO}_{3}{ }^{-}$) at two levels ( $\mathrm{N} 0$ and $\mathrm{N} 20$, respectively corresponding to 0 and 20 $\left.\mathrm{kg} \mathrm{N} \mathrm{ha}^{-1}\right)$; ii) sowing density at four levels (D1=125, D2=25, D3=8 and $\mathrm{D} 4=4$ plants $\mathrm{m}^{-2}$ ) with a fixed distance of $0.8 \mathrm{~m}$ interrow; iii) in a splitplot design with three block replications where the $\mathrm{N}$ top-dressing was assigned to main plot and sowing density was assigned to the split plots. Elementary plots were $5 \times 8 \mathrm{~m}$.

\section{Plant measurements}

At 44, 73 and 103 DAS the area of leaves and the plant fresh biomass were measured on samples of $1 \mathrm{~m}$ along the row. Leaf area was determined through the Winrhizo pro (Regent Instruments, Inc., Québec, QC, Canada) image analysis software after acquiring images with a desktop scanner installed at the field premises. At harvest (180 days after sowing) the number of plants $\mathrm{m}^{-2}$ was measured and the yield of the chia product, consisting of dry indeiscent fruits commonly called seeds, was determined on a fresh basis. The ratio of ripe to unripe fruits was determined on a subsample of 15 inflorescences per plant on 5 plants per plot where fruits were manually separated based on colour and degree of filling. The water content was measured after oven drying at $70^{\circ} \mathrm{C}$.

\section{Statistical analysis}

The effects of plant density and nitrogen fertilisation were assessed by a mixed effect model estimated by restricted maximum likelihood. A mixed effects model incorporates both fixed effects, associated to the levels of the experimental factors, and single or multiple levels random effects that allow grouping effects as random variations around the population mean (Pinheiro and Bates, 2000). As a consequence of including of one or more random terms a correlation structure between observations belonging to the same group is incorporated in the model; this is called induced correlation (Zuur et al., 2009). Scouting analysis was performed to assess data normality and the presence of possible interactions between factors. To test the effects of plant density and mineral top-dressing fertilisation on plant biometric variables several models were computed. A multilevel mixed effects model was used and since residuals analysis revealed the presence of heteroschedasticity a variance function was used to model the within group error variance structure. For yield, a mixed effects analysis of covariance (ANCOVA) model using $\mathrm{N}$ top-dressing and the effective plant density at harvest as a continuous covariate was computed, while the effect on seed maturation was tested within a mixed effect model using the block as a random effect.

Models with or without a variance structure were compared through the Akaike information criterion (AIC) and the Bayesian information criterion (BIC). Post hoc comparisons for mean separation were conducted with the test of Tukey.

Statistical analysis was performed by $\mathrm{R}$ software (R Development Core Team, 2008) using the library nlme for mixed effects modelling (Pinheiro et al., 2013) and library multcomp (Hothorn et al., 2008) for post hoc comparison.

\section{Results and discussion}

The production of leaves was very high in all treatments, on average $10.96 \mathrm{t} \mathrm{ha}^{-1}$ at $18.9 \%$ dry matter content, and this resulted in high values of leaf area index (LAI) (Figure 1). For the randomised block design with repeated measures, used in this study, LAI and plant biomass were modelled as a function of plant density and DAS as fixed effects. The $\mathrm{N}$-fertilisation treatment was not significant therefore it was retained only as a random term, to account for the lack of independence between sub-replicates at the block level. In the mixed model a three level random effect was included, where $\mathrm{N}$-fertilisation was nested within the block effect, the third level of grouping was given by the plant densities in order to account for the auto-correlation due to the repeated measures.

The resulting model therefore was:

$$
\mathrm{Y}_{\mathrm{idjk}}=\beta_{0}+\beta i+\beta d+b j+b j k+b j k i+\mathrm{e}_{i d j k}
$$

where:

$\beta$ is the intercept;

$\beta_{i}$ is the vector of fixed effect of plant density, with the index $i=1, \ldots 4$ representing the four plant densities (D1, D2, D3, D4);

$\beta_{d}$ is the fixed effect of the days after sowing (DAS) $d=1 \ldots 3$;

$b_{j}$ and $b_{j k}$ and $b_{j k i}$ are the random effects terms respectively:

$b_{j}$ the block effect with $i=1, \ldots .3$

$b_{j k}$ the nitrogen fertilisation effect $k=1 . . .2$ nested within the block $\mathrm{j}=1, \ldots 3$;

$\mathrm{b}_{j k i}$ the plant density nested within each nitrogen fertilisation level, nested within each block;

$\mathrm{e}_{i d j k}$ denotes the within group errors.

Since residuals were found heteroschedastic, with the variability increasing with time, a variance function was included using DAS as a variance covariate. We used the variance function belonging to the class varFixed (available in the Rcran nmle library) that assumes $\mathrm{e}_{d} \mathrm{~N}\left(0, \mathrm{~s}^{2} \times \mathrm{DAS}_{d}\right)$ allowing within-group variance to increase linearly with DAS. The models, with or without the variance function, were compared in terms of both AIC and BIC criteria. The new model showed better performances having lower AIC and BIC. This procedure was applied to all of the models yielding consistent results.

Results of statistical models show that plant biomass and LAI increased up to $103 \mathrm{DAS}$, the top-dressing mineral fertilisation treatment was not significant while plant density significantly affected all measured variables, no interactions between fixed factors was found to be significant.

Aboveground biomass and LAI increased with time until the beginning of flowering (103 DAS) and values of D1 were not significantly different than those of D2 and values of D3 were not significantly different than those of D4. An example for LAI is shown in Figures 1 and 2. Fresh and dry vegetative biomass production had a similar trend and reached values ranging respectively between 50.87 (D4) and 59.71 (D1) $\mathrm{t} \mathrm{ha}^{-1}$ and between 4.26 (D4) and 5.04 (D1) $\mathrm{t} \mathrm{ha}^{-1}$ at the beginning of flowering (103 DAS).

Peiretti (2010) reports that leaves of chia may represent a valuable 


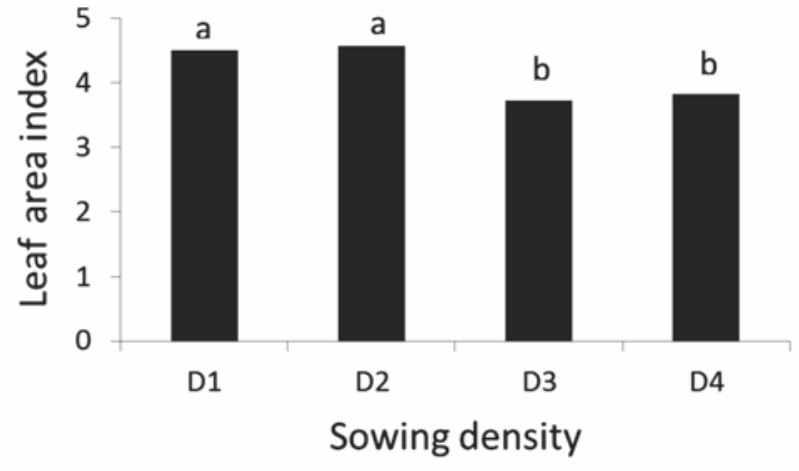

Figure 1. Chia (Salvia hispanica L.) leaf area index as a function of sowing density treatment (averages of 4 sampling dates). Values with different letters are significantly different at the test of Tukey $(\mathbf{P}<0.005)$.

forage due to the high percentage of 3 , especially in early stages of development. Also, use as a fresh vegetable may be explored. Values of biomass are in line or higher than that reported for other environments (Bochicchio et al., 2015). The large canopy values found in this experiment are linked to a late flower induction due to photoperiod sensitivity. On the other hand, due to late flowering (first week of October) peaks of low temperature in autumn interrupted maturation processes and only about $1 / 4$ of the total fruit weight was made of ripe fruits.

All plants survived at harvest at the lowest sowing density D4 (and this corresponds to null death or lodging) whereas plant death increased with sowing density up to $55 \%$, with a lower number of survived plants in the treatments with $\mathrm{N}$ top-dressing in D1 and D2. The effect of fertilisation however was not significant.

The yield of ripe fruits at 5.4\% water content ranged between 133.7 $\mathrm{kg} \mathrm{ha}^{-1}$ (D4 N20) to $518.4 \mathrm{~kg} \mathrm{ha}^{-1}$ (D1 N0). Yield for treatment D1 was significantly higher than that of D3 and D4 $(\mathrm{P}<0.05)$.

A reduction of yield was recorded in plots fertilised with $\mathrm{N}$ in topdressing, but it was non-significant at the analysis of variance where sowing density and nitrogen top-dressing where used as covariates. Nevertheless, the detrimental effect of N20 on yield was significant at $\mathrm{P}<0.05$ when it was tested using the effective plant density at harvest as a continuous variable through a mixed effect ANCOVA that yielded the following equation:

$$
\mathrm{Y}=76.75+4.769 * \mathrm{P}_{\mathrm{dh}}+104.73 * \mathrm{~N}_{0 \mathrm{~T}} \mathrm{R}_{\text {adj }}^{2}=0.56
$$

where:

$\mathrm{Y}=$ yield $\left(\mathrm{kg} \mathrm{ha}^{-1}\right)$;

$\mathrm{P}_{\mathrm{dh}}=$ plant density at harvest (plants $\left.\mathrm{m}^{-2}\right)(\mathrm{P}<0.001)$;

$\mathrm{N}_{0 \mathrm{~T}}=$ treatment with no nitrogen in top-dressing $(\mathrm{P}<0.05)$.

In general the response of chia to nitrogen is reported to be controversial (De Kartzow, 2013). In our experiment lack of response to $\mathrm{N}$ topdressing for LAI and biomass can be explained by the nitrogen content of organic amendment, whereas a yield reduction with $\mathrm{N}$ top-dressing can be only partly commented in terms of plant death or lodging. Other effects, e.g., linked to phenology need to be further investigated. In our case for instance the rate of mature seed to total seed production was higher in unfertilised plots ( $26 \%$ in N0 versus $21 \%$ in N20) however the P-value corresponding to this difference was only 0.11 . Lodging also increased the variability of data: for instance coefficients of variation of plant density at harvest ranged from 0 in treatment D4 to as high as $65.7 \%$ in treatment D2 with nitrogen top-dressing.

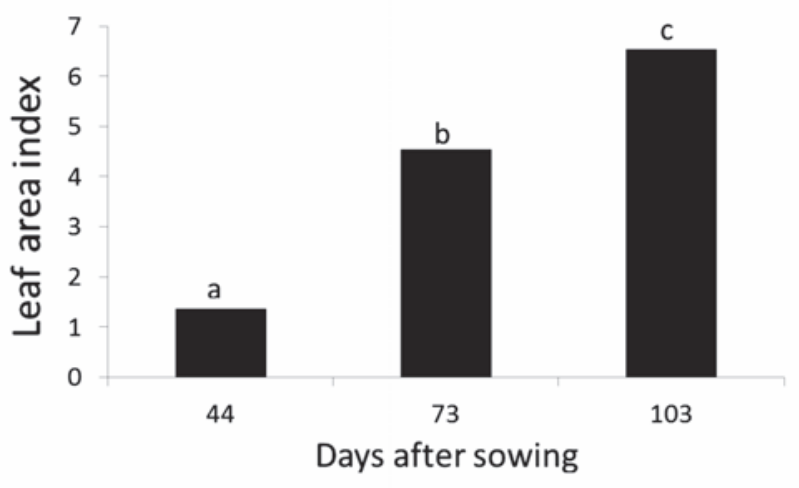

Figure 2. Chia (Salvia hispanica L.) leaf area index as a function of days after sowing (averages of 3 sowing densities). Values with different letters are significantly different at the test of Tukey $(\mathbf{P}<0.01)$.

The production level of D1 was in line with lower limits of yield attained in some environments of Central America where it is traditionally grown, but below those reached in the best growing conditions (Ayerza and Coates, 2009). As mentioned, the combination of phenology, winter kill and lodging affected fruit yield, therefore our data are only indicative of the chia production potential outside the geographic region of origin, and effects of $\mathrm{N}$-fertilisation need to be further investigated.

\section{Conclusions}

First results indicate that growth and yield of chia were highest at high sowing density. A reduction in yield as an effect of $\mathrm{N}$ top-dressing was detected; this corresponds to controversial reports on the effect of $\mathrm{N}$ on chia and needs to be investigated further.

Based on first results, pursuing agronomical trials for Salvia hispanica L. in herbaceous systems of southern Italy seems worthwhile: it might represent an interesting summer crop for the production of fruits, in particular if longer-day genotypes can be found in order to obtain earlier flowering. In spite of late flowering, a short-day genotype from traditional growing areas used in this experiment produced fruit yields comparable to those attained in low productivity environments of Central America, but only at the highest sowing density. On the other hand, a high leaf area and biomass were produced, with possible perspectives for forage or even fresh consumption.

\section{References}

Ayerza R, Coates W, 2002. dietary levels of chia: influence on hen weight, egg production and sensory quality for two strains of hens. Br. Poultry Sci. 43:283-90.

Ayerza R, Coates W, 2006. Influence of chia on total fat, cholesterol, and fatty acid profile of holstein cow's milk. Rev. Cientif. U.C.E.S. X:40-9.

Ayerza R, Coates W, 2009. Influence of environment on growing period and yield, protein, oil and linolenic content of three chia (Salvia hispanica L.) selections. Ind. Crops Prod. 30:321-4.

Bochicchio R, Philips TD, Lovelli S, Labella R, Galgano F, Di Marisco A, Perniola M, Amato M, 2015. Innovative crop productions for healthy 
food: the case of chia (Salvia hispanica L.). In: A. Vastola (Ed.), The sustainability of agro-food and natural resource systems in the Mediterranean basin. Springer-Verlag, Berlin and Heidelberg, Germany, pp 29-45.

De Kartzow A, 2013. Estudio de pre factibilidad técnico - Económica del cultivo de chía (Salvia hispánica L.) en Chile. Fundación para la Innovación Agraria (FIA), Santiago, Chile. Available from: http:/www.fia.cl/Portals/0/UCP/Documentos/Informe\%20Est\%20Te c\%20Econ\%20de\%20Chia\%20en\%20Chile.pdf

European Commission, 2009. 2009/827/EC: Commission Decision of 13 October 2009 authorising the placing on the market of Chia seed (Salvia hispanica) as novel food ingredient under Regulation (EC) No 258/97 of the European Parliament and of the Council (notified under document C(2009) 7645). In: Official Journal L 294, 11/11/2009, pp 14-15.

Hothorn T, Bretz F, Westfall P, 2008. Simultaneous inference in general parametric models. Biometr. J. 50:346-63.

Iuss working Group, 2006. World reference base for soil resources 2006. World Soil Resources Report No. 103. Food and Agriculture Organisation, Rome, Italy.

Peiretti PG, 2010. Ensilability characteristics of chia (Salvia hispanica L.) during its cycle and fermentiation pattern of its silages affected by wilting degrees. Can. J. Agricult. Sci. 44:33-6.

Peiretti PG, Meineri G, 2008. Effects on growth performance, carcass characteristics, and the fat and meat fatty acid profile of rabbits fed diets with chia (Salvia hispanica L.) seed supplements. Meat Sci. 80:1161-21.

Pinheiro JC, Bates DM, 2000. Mixed-effects models in S and S-PLUS. Springer, Berlin, Germany.

Pinheiro J, Bates D, DebRoy S, Sarkar D, R Development Core Team, 2013. nlme: linear and nonlinear mixed effects models. R package version 3. Available from: http://CRAN.R-project.org/package=nlme Pozo Pozo SA, 2010. Alternativas para el control químico de malezas anuales en el cultivo de la Chía (Salvia hispánica) en la granja ECAA, provincia de Imbabura, memoria de título. Pontificia Universidad Catolica del Ecuador, Ibarra, Ecuador.

R Development Core Team, 2008. R: A language and environment for statistical computing. R Foundation for Statistical Computing, Vienna, Austria. Available from: http://www.R-project.org

Zuur A, Ieno EN, Walker N, Saveliev AA, Smith GM, 2009. Mixed effects models and extensions in ecology with R. Springer, Berlin, Germany. 